\section{Changes in perinatal health in two birth cohorts (1997/1998 and 2010) in São Luís, Maranhão State, Brazil}

\author{
Mudanças na saúde perinatal em duas coortes de \\ nascimento (1997/1998 e 2010) em \\ São Luís, Maranhão, Brasil
}

\author{
Cambios en la salud perinatal en dos cohortes de \\ nacimiento (1997-1998 y 2010) en \\ São Luís, Maranhão, Brasil
}

Antônio Augusto Moura da Silva ${ }^{1}$

Rosângela Fernandes Lucena Batista 1

Vanda Maria Ferreira Simões 1

Erika Barbara Abreu Fonseca Thomaz 1

Cecília Cláudia Costa Ribeiro 1

Fernando Lamy-Filho 1

Zeni Carvalho Lamy 1

Maria Teresa Seabra Soares de Britto e Alves 1

Flávia Helen Furtado Loureiro 1

Viviane Cunha Cardoso 2

Heloisa Bettiol 2

Marco Antonio Barbieri 2

\section{Resumo}

O objetivo deste estudo foi analisar as mudanças na saúde perinatal em duas coortes de nascimento realizadas em 1997/1998 e 2010, em São Luís, Maranhão, Brasil. Um total de 2.493 nascidos vivos foi incluído em 1997/1998 e 5.166 em 2010. A taxa de baixo peso ao nascer (BPN) não se modificou (8,5\% em 1997/1998 e 8,6\% em 2010). A taxa de nascimento pré-termo (NPT) também permaneceu estável (13,2\% em 1997/1998 e 13\% em 2010). Nascimentos em adolescentes e em mulheres sem companheiro decresceram. A escolaridade materna e a cobertura do pré-natal aumentaram. A taxa de restrição de crescimento intrauterino (RCIU) diminuiu de 13,3\% para 10,6\% ( $p<0,001)$. A taxa de mortalidade perinatal foi reduzida de 36,6 para 20,7 por mil $(p<0,001)$ e a taxa de mortalidade infantil diminuiu de 28,5 para 12,8 por mil ( $p<0,001)$. A taxa de cesárea (TC) aumentou de 34,1\% para 47,5\% ( $p<0,001)$. Apesar das mudanças favoráveis nas variáveis sociodemográficas, comportamentais e de serviços de saúde e da redução nas taxas de RCIU, mortalidade perinatal e infantil, as taxas de BPN e NPT permaneceram estáveis, enquanto a TC aumentou.

Low Birth Weight Infant; Premature Birth; Fetal Growth Retardation; Cesarean Section; Cohort Studies
Recém-Nascido de Baixo Peso; Nascimento Prematuro; Retardo do Crescimento Fetal; Cesárea; Estudos de Coorte 


\section{Introduction}

Temporal analysis of maternal and child health indicators allows evaluating socioeconomic changes and advances and setbacks in the availability and quality of health services 1 . Repeated population-based studies 2,3 are best suited to analyze changes in most perinatal health indicators when compared to information systems analysis. Coverage problems, underreporting, and lack of standardized information, especially for gestational age (GA), in the Brazilian Live Birth Information System (SINASC) limits the use of data for assessing changes in perinatal indicators over time ${ }^{4}$. Thus, serial cohort studies are one of the most important tools for the evaluation of temporal changes in social determinants and their effects on health conditions 5,6.

Population-based cohort studies have been conducted in two Brazilian cities, allowing temporal analysis of maternal and child health indicators. In Ribeirão Preto, São Paulo State, Southeast Brazil, the first cohort was started in 1978/1979, followed by a second in 1994. In Pelotas, Rio Grande do Sul State, in the South of Brazil, three cohort studies were started at 11-year intervals (1982, 1993, and 2004), allowing evaluation of temporal trends in maternal and child health indicators.

Preterm birth (PTB) rates have increased even in developed countries that have already achieved advances in the organization of health services for women and children $2,7,8,9,10,11$. The global PTB rate was estimated at $11.1 \%$ in 2010 , with marked continental differences ${ }^{12}$. Cohort studies in the Southeast and South of Brazil have indicated an increasing PTB trend since the 1990s (9.10), reaching 13.6\% in Ribeirão Preto-1994 13 and $14.7 \%$ in Pelotas-2004 14.

Low birth-weight (LBW) rates have also increased around the world in the last 20 years $2,7,8,9,10,11$. The LBW rate increased from $8.5 \%$ in 1996 to $9.1 \%$ in Brazil's state capitals 15. Temporal analysis in the Ribeirão Preto cohorts also showed an increase in the LBW rate from $7.2 \%$ in $1978 / 1979$ to $10.6 \%$ in 199416 , but comparison of the 1982 and 2004 birth cohorts showed that LBW has not increased in Pelotas 14 .

Intrauterine growth restriction (IUGR) rate, estimated as the percentage of small-for-gestational-age (SGA) newborns, was $27 \%$ in low and middle-income countries in 2010 17. In Brazilian cohorts, the rate increased in Ribeirão Preto from $1978 / 1979$ to 199418 , but in Pelotas it decreased from $14.8 \%$ in 1982 to $12 \%$ in 200414 .

The cesarean rate, another important indicator of maternal and child health, increased from $38 \%$ in 2001 to $48.8 \%$ in 2008 in Brazil 19. The same trend was seen in the cohorts in Ribeirão Preto, where cesareans accounted for half of all births in 1994 20, a rate far higher than the levels considered acceptable by the World Health Organization (WHO) 21,22.

From 1930 to 1970, Brazil witnessed a reduction of approximately $1 \%$ per year in the infant mortality rate (IMR). However, the IMR did not decrease evenly between the neonatal and postnatal components. Neonatal deaths represented $68 \%$ of the IMR in 2008 , and their reduction from 2000 to 2008 (3.2\% per year) continued to be less than the drop in the postnatal mortality rate (PNMR) (8.1\% per year) 19 . The two components of the IMR decreased by similar proportions in Ribeirão Preto from 1978-79 to 2004 23. In Pelotas, the neonatal and post-neonatal mortality rates declined from 1982 to 1993 , but the neonatal component failed to show a clear decline from 1993 to 20047.

The stillbirth rate (SBR) has also decreased in Brazil. Data for Brazil's state capitals show that the SBR fell from 14.1 per 1,000 in 1996 to 9.3 per 1,000 in 2010 15. In Pelotas, the late fetal mortality rate has also declined substantially in the last three decades 7 .

São Luís, Maranhão State, started its first birth cohort in 1997-1998 24, followed by a second in 2010. The two consecutive cohorts allowed a temporal analysis of maternal and child health in the city. The objectives of the current study were to analyze perinatal outcomes, sociodemographic and behavioral factors and use of health and perinatal services in a new birth cohort (BRISA - Brazilian Ribeirão Preto and São Luís birth cohort studies) started in 2010 and to compare these indicators to those from a cohort started 12 years earlier.

\section{Methods}

\section{Study site}

São Luís is the capital of Maranhão State in Northeast Brazil, one of the country's poorest regions. The city's Human Development Index was 0.658 in 2000, increasing to 0.768 in 2010, currently ranking 249 th in the country 25 . The city's population was 1,014,837 in 2010 (Brazilian Institute of Geography and Statistics. http:/ / www.censo2010.ibge.gov.br/sinopse/index. php? uf=21\&dados=1, accessed on 12/Jul/2012).

The data in the two birth cohorts are population-based. The first cohort was assembled from March 1997 to February 1998 and included 2,831 hospital births. Details of the methods have been published elsewhere 24 . The second cohort 
called BRISA, was assembled from January to December 2010 and consisted of 5,236 hospital births involving a population-based sample of deliveries in the municipality.

In São Luís, hospital births comprised 96.3\% of the $1997 / 1998$ births 24 and $98 \%$ of the 2010 births. Maternity hospitals with fewer than 100 deliveries per year were excluded from the two studies (2.2\% of deliveries in 1997/ 1998 and 3.3\% in 2010). The target population thus consisted of $94.1 \%$ of all deliveries in $1997 / 1998$ and $94.7 \%$ in 2010 .

The sample was stratified according to hospital of birth. Probability of selection was proportional to the number of deliveries in each hospital. Systematic sampling was performed in each maternity hospital. All live births and stillbirths were listed by order of occurrence. A random number from 1 to 7 in 1997/1998 and from 1 to 3 in 2010 was generated to determine the random start in each hospital. Thus, one out of every seven deliveries in 1997/1998 and one out of three in 2010 were selected at random for interviewing the mothers. Losses due to refusal or early discharge totaled $5.8 \%$ in $1997 / 1998$ and $4.6 \%$ in 2010 .

The current study only included data for live births $\geq 20$ weeks of GA or weighing $\geq 500$ g and born to mothers residing in the municipality. In 1997/1998, 290 live births to non-resident mothers and 48 stillbirths were excluded, so the final sample included 2,493 births.

In 2010, 21,401 births occurred at the selected units, one-third of which were picked by drawing lots $(7,133)$. Of these, 5,475 births were to mothers residing in the municipality for at least three months and therefore eligible for the study. The sample consisted of 5,236 postpartum women, and after the exclusion of 70 stillbirths it consisted of 5,166 births (Figure 1).

The sample size for 2010 was calculated based on the number of hospital births that had occurred in São Luís in 2007. The minimum sample size was set at 5,000 births. This sample size allowed estimating prevalence rates around $50 \%$ (entering $50 \%$ as the estimated prevalence that results in the highest sample size) with $2 \%$ relative precision and $99 \%$ confidence level. It was also possible to compare two proportions considering a $5 \%$ probability of type I error and $80 \%$ study power, working with the maximum product of $\mathrm{p} \times \mathrm{q}$ (50\% proportion of the event) and setting the minimum significant difference for detection at $4 \%$. For prevalence rates of less than $50 \%$ it would be possible to detect smaller differences (it was possible to detect a $3 \%$ relative difference for a prevalence rate of $10 \%$ and a $2 \%$ relative difference for a prevalence rate of 5\%) 26 .
The following descriptions apply to both cohorts unless stated otherwise.

Properly trained undergraduate health students collected the data. A pilot study was conducted with simulation of all research steps at all hospital units for 24 hours. Supervision and quality control procedures were performed daily.

Data collection was performed in shifts, usually from 7:00 PM to 7:00 AM for the first shift and from 7:00 AM to 7:00 PM for the second. A form was elaborated for listing all births and recording the interviews, containing the ordered list of births, mother's name and address, whether she resided in the municipality (yes/no), date and time of delivery, number of newborns, whether the interview was held (yes/no), refusal, or discharge. Births were registered in order of occurrence with the time of birth.

The mothers were interviewed during the first 24 hours postpartum. Two standardized questionnaires with questions on the mother and newborn were used. The variables were monthly family income in minimum wages $(\leq 1$, 1.1 to $1.9,2$ to $2.9,3$ to $4.9,5$ to 9.9 , and $\geq 10$ ), head-of-family's occupation (non-manual, managerial and upper-level professionals, mediumlevel managerial, skilled manual, semi-skilled manual, unskilled manual, unemployed), number of household members ( 1 to $4, \geq 5$ ), economic class according to the Brazilian Economic Classification $(\mathrm{CEB})$ - (A, B, C, D, and E, with class A being the wealthiest and best educated and class E the poorest and least educated), maternal work outside the home (yes/no), maternal schooling in years (none, 1-4, 5-8, 9-11, $\geq 12$ ), maternal age in years $(<20,20-34, \geq 35)$, self-reported maternal skin color (white, black, brown, or other), marital status (married, common-law union, or single), religion (Catholic, Evangelical, Spiritist, or other), parity (1, 2, 3-4, $\geq 5$ ), alcohol consumption during pregnancy (yes if at least one dose of alcoholic beverage per week or no otherwise), maternal smoking during pregnancy (yes if at least one cigarette per day during pregnancy or no otherwise), maternal consumption of coffee during pregnancy (yes if at least one cup a day or no otherwise), previous stillbirth (yes/no), previous miscarriage or induced abortion (yes/no), prenatal care during the index pregnancy (yes/ no), number of prenatal visits $(0,1-3,4-5, \geq 6)$, time at first prenatal visit (first, second, or third trimester of pregnancy), category of prenatal care (Brazilian Unified National Health System - SUS, health plan/insurance, or out-of-pocket), type of delivery (vaginal or cesarean), tubal ligation following cesarean delivery (yes/no), professional that assisted the delivery (physician, nurse, or other), whether the same physician provided the 


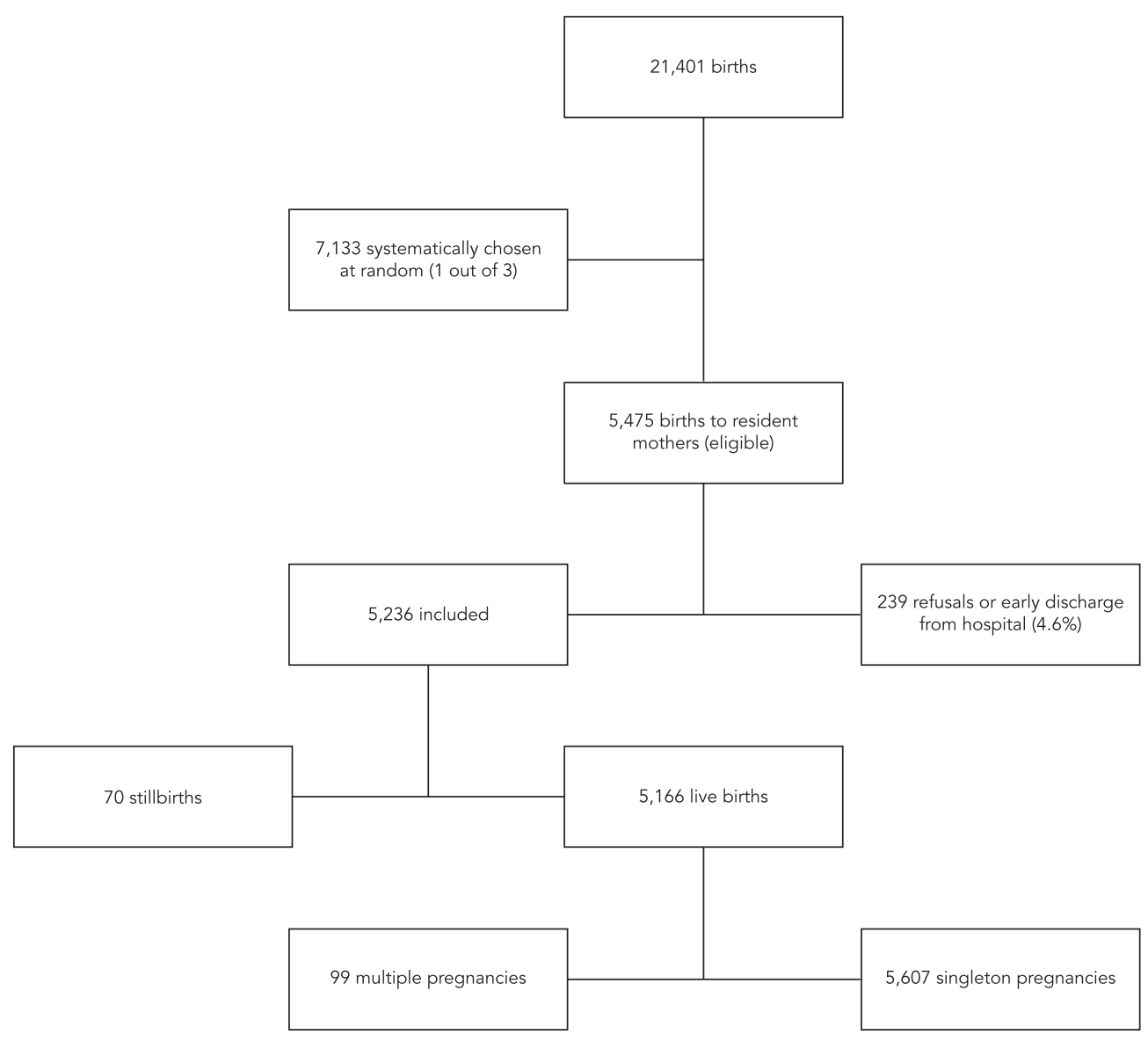

prenatal care and assisted the delivery (yes/no), category of admission for labor and childbirth (SUS, health plan/insurance, or out-of-pocket), newborn's sex (male, female), LBW defined as < 2,500g (yes/no), PTB defined as < 37 weeks GA (yes/no), newborn's weight-for-GA classification according to Williams et al. 27 (small, adequate, or large for GA), professional that assisted the newborn (pediatrician/neonatologist, obstetrician, anesthesiologist, nurse, nursing technician, or other), and determination of Apgar score in the delivery room (yes/no).

The monthly minimum wage was BRL 120.00 in 1997, corresponding to USD 110.80, and BRL 510.00 in 2010, corresponding to USD 291.54.

Newborns were weighed with no clothing using electronic scales accurate to $5 \mathrm{~g}$ immediately after delivery. IUGR rate was estimated as the percentage of SGA $<10$ percentile according to Williams et al. 27.

GA was based on the date of the last normal menstrual period (LNMP) reported by the mother. Day 15 was imputed for all cases for which the date of the LNMP was unknown. Birth weights above the 99th percentile of the British reference curve 28 , considered inconsistent with GA, namely 69 cases in 1997 and 104 in 2010, were recoded as missing. Cases of implausible GA (less than 20 and more than 43 weeks) were also classified as missing. GA was imputed in a regression model containing birth weight, parity, monthly per capita family income, and newborn's sex. In 1997/1998, 204 cases were imputed (8.2\%), 9 as preterm and 195 as term births whereas in 2010 a total of 452 cases were imputed (8.7\%), 43 of which as preterm and 409 as term births. 
Perinatal mortality rate (PMR) was estimated by dividing the number of stillbirths with 20 or more weeks GA plus early neonatal deaths (up to the 6th day of life) by the total number of live births and stillbirths multiplied by 1,000. SBR was calculated by dividing the number of stillbirths by the total number of live births and stillbirths multiplied by 1,000 . Neonatal mortality rate (NMR) was calculated by dividing the number of deaths of infants less than 28 days of age by the total number of live births multiplied by 1,000 . The IMR was calculated by dividing the number of deaths of infants less than one year of age by the total number of live births multiplied by 1,000 . Neonatal and infant deaths for the BRISA cohort were identified through linkage of birth cohort data with mortality registry data. Probabilistic record linkage using the variables mother's name and newborn's date of birth and sex was performed using the RecLink statistical package 29. Following three stages (standardization, blocking, and record pairing), pairs were classified based on threshold scores into true, false, and doubtful. Final doubts were checked and corrected manually.

\section{Data processing and statistical analysis}

Data were entered in duplicate in Microsoft Office Access 2007 (Microsoft Corp., USA), and the two entries were compared and errors corrected. Data were analyzed with Stata 12.0 (Stata Corp., College Station, USA). Absolute frequencies and percentages were calculated in descriptive analyses. The chi-square test was used to compare proportions between the two birth cohorts. The 95\% confidence interval $(95 \% \mathrm{CI})$ was calculated for PMR, SBR, IMR, and NMR based on the Poisson distribution.

\section{Ethical aspects}

The study complied with Resolution n. 196/96 of the Brazilian National Health Council and its complementary norms. Mothers who agreed to participate in the study gave written informed consent. Participants had the option to drop out of the study at any time during without any harm to themselves or their families. The project and the informed consent form were approved by the Ethics Research Committee of the UFMA University Hospital (protocol n. 4771/2008-30).

\section{Results}

In 2010, a total of 5,166 births were included in the study, considering only live births to moth- ers residing in São Luís. Most births (84.4\%) occurred at the five main city hospitals (public or outsourced by the SUS).

Table 1 lists the families' socioeconomic, demographic, reproductive, and lifestyle characteristics. Table 2 shows the prenatal care and childbirth characteristics. Prenatal care coverage was $98 \%$. The SUS was responsible for $79.9 \%$ of the prenatal care visits and $84.1 \%$ of the deliveries (Table 2).

Table 3 lists some newborn characteristics and perinatal and health care outcomes. The LBW rate was $8.6 \%$ and the PTB rate was $12.9 \%$. Only $48.9 \%$ of the newborns were attended by a pediatrician or neonatologist in the delivery room. Apgar score was determined in $98.2 \%$ of the newborns.

Table 4 lists the changes in socioeconomic and perinatal health indicators between the 1997/1998 and 2010 cohorts. The LBW or PTB rates did not change during the study period, but important indicators improved. Maternal schooling increased. Prenatal care coverage and first prenatal visit in the first trimester increased, and there were decreases in the IUGR rate and percentage of single mothers and those younger than 20 years. The IMR, NMR, and PMR also dropped sharply. On the negative side, there was an increase in the cesarean rate (Table 4 ).

\section{Discussion}

Temporal analysis of maternal and child health indicators in São Luís comparing the 1997/1998 cohort with the 2010 BRISA cohort shows that LBW and PTB rates remained stable while the IUGR rate and IMR decreased. There was also a favorable evolution of various socioeconomic and demographic factors associated with these conditions, such as a decline in teenage deliveries, increased maternal schooling, lower percentage of births to single mothers, and increased overall prenatal coverage and first prenatal visit in the first trimester. Despite these favorable indicators, the cesarean rate increased.

The LBW rate remained stable between the two study periods in the São Luís cohorts. A similar result was observed in the 1982, 1993, and 2004 cohorts in Pelotas, where this rate also stabilized around $9-10 \% 14$. However, these findings differed from Ribeirão Preto, where the LBW rate increased from $7.2 \%$ in $1978 / 1979$ to $10.6 \%$ in $1994{ }^{30}$. Based on birth registry data, an increase in LBW rate was also observed in Brazil's state capitals as a whole 15 , but not in the country as a whole 31 . 
Table 1

Socioeconomic, demographic, reproductive and life-style characteristics of women. BRISA cohort study, São Luís, Maranhão State, Brazil, 2010

\begin{tabular}{|c|c|c|}
\hline Variables & $\mathrm{n}$ & $\%$ \\
\hline \multicolumn{3}{|l|}{ Monthly family income (minimum wages) } \\
\hline$\leq 1.0$ & 764 & 14.8 \\
\hline $1.1-1.9$ & 1,244 & 24.1 \\
\hline $2.0-2.9$ & 820 & 15.9 \\
\hline $3.0-4.9$ & 656 & 12.7 \\
\hline $5.0-9.9$ & 486 & 9.4 \\
\hline$\geq 10.0$ & 267 & 5.2 \\
\hline Missing & 929 & 18.0 \\
\hline \multicolumn{3}{|l|}{ Occupation of the family head } \\
\hline Managers and higher levels professionals & 571 & 11.0 \\
\hline Medium level administrators & 487 & 9.4 \\
\hline Skilled manual workers & 248 & 4.8 \\
\hline Semiskilled manual workers & 1,853 & 35.9 \\
\hline Unskilled manual workers & 1,388 & 26.9 \\
\hline Unemployed & 447 & 8.6 \\
\hline Missing & 172 & 3.3 \\
\hline \multicolumn{3}{|l|}{ Number of household members } \\
\hline $1-4$ & 3,544 & 68.6 \\
\hline$\geq 5$ & 1,622 & 31.4 \\
\hline \multicolumn{3}{|l|}{ Economic class } \\
\hline A & 145 & 2.8 \\
\hline B & 788 & 15.2 \\
\hline C & 2,603 & 50.4 \\
\hline $\mathrm{D}$ & 1,125 & 21.8 \\
\hline $\mathrm{E}$ & 195 & 3.8 \\
\hline Missing & 310 & 6.0 \\
\hline \multicolumn{3}{|l|}{ Self-reported skin color } \\
\hline White & 958 & 18.5 \\
\hline Black & 661 & 12.8 \\
\hline Mulatto & 3,469 & 67.2 \\
\hline Other & 78 & 1.5 \\
\hline \multicolumn{3}{|l|}{ Religion * } \\
\hline Catholic & 2,720 & 52.7 \\
\hline Evangelical & 1,418 & 27.5 \\
\hline Spiritist & 27 & 0.5 \\
\hline Other & 16 & 0.3 \\
\hline None & 981 & 19.0 \\
\hline \multicolumn{3}{|l|}{ Maternal job outside the home } \\
\hline Yes & 1,737 & 33.6 \\
\hline No & 3,429 & 66.4 \\
\hline \multicolumn{3}{|l|}{ Parity } \\
\hline 1 & 2,443 & 47.3 \\
\hline 2 & 1,592 & 30.8 \\
\hline $3-4$ & 948 & 18.4 \\
\hline$\geq 5$ & 183 & 3.5 \\
\hline
\end{tabular}

(continues) 


\begin{tabular}{lcc} 
Table 1 (continued) & & \\
\hline Variables & $\mathbf{n}$ & \\
\hline Previous stillbirth & & 2.9 \\
$\quad$ Yes & 151 & 97.1 \\
No & 5,015 & 21.6 \\
Previous abortion & 1,115 & 78.4 \\
$\quad$ Yes & 4,051 & 14.4 \\
No & & 85.6 \\
Alcohol consumption during pregnancy & 746 & \\
Yes & 4,420 & 4.0 \\
No & & 96.0 \\
Maternal smoking during pregnancy & 208 & 88.6 \\
Yes & 4,958 & 11.4 \\
No & & \\
Maternal coffee consumption during pregnancy * & 4,576 & \\
Yes & 589 & \\
No &
\end{tabular}

* Missing values were excluded.

PTB rates were also stable in the two periods in the São Luís cohorts, at around 13\%. These data differ from the findings in Ribeirão Preto, where the PTB rate increased between $1978 / 1979$ and 1994, reaching $13.6 \%$ in the latter 13 and in Pelotas, increasing between 1982 and 2004 , reaching $14.7 \% 14$. A review study based on birth registry data also demonstrated that the PTB rate is increasing in Brazil 32. Another review of population-based studies reached the same conclusion 33 .

A $23.7 \%$ reduction in the IUGR rate was observed between the two periods in the São Luís cohorts (1997/1998 and 2010). These data differ from the trend in Ribeirão Preto, where the rate increased from 1978/1979 to 1994, reaching 18\% in the latter 18 . Comparative data from the Pelotas cohorts showed a reduction in the IUGR rate from 1982 to 1993, but the rate later increased, reaching $12 \%$ in 200414 .

The reason for a drop in the IUGR rate while LBW and PTB remained stable in the São Luís cohorts between 1997/1998 and 2010 are not fully understood and need further elucidation. The IUGR rates in Brazil may have increased during the 1990s up to 2000, and may have decreased more recently. Since the São Luís data presented here were collected more recently than the Pelotas and Ribeirão Preto data, the current study may have detected the more recent downward national trend in IUGR.

Various studies have identified and discussed the paradoxical trend of increasing LBW rate in parallel with favorable evolution in various so- cioeconomic and demographic factors and improvement of health services in the last two decades, especially in more developed regions of Brazil 31,34,35. The increase in LBW and PTB rates has been attributed to the increasing multiple pregnancy rate 36 , increased use of assisted reproduction techniques, and improved medical care leading to a reduction in stillbirths, although simultaneously leading to an increase in LBW and/or PTB rates 31 and iatrogenic complications from the excessive number of cesarean deliveries $2,7,13$. Recent stabilization of the LBW and PTB rates in São Luís suggests that the increases observed in PTB and LBW rates in previous decades in Brazil may be leveling out. Consistent with the present data, a downward IUGR rate and stabilization of the LBW rate were detected recently in Porto Alegre, a city in the South of Brazil 37.

The São Luís cohorts showed a downward trend in IMR, dropping to less than half the rate observed in $1997 / 1998$, reaching 12.8 per 1,000 live births in 2010. The Ribeirão Preto and Pelotas cohorts also showed a reduction in the infant mortality rate. The IMR in Ribeirão Preto was 17 per 1,000 live births in 199438 and in Pelotas it was 19.4 per 1,000 in 2004 39. A decrease in IMR was also found in Porto Alegre from 1995 to 1999 , reaching 12.2 per 1,000 in the latter 40 . These findings are consistent with the reduction in IMR observed in Brazil as a whole in recent decades 19 .

Neonatal and perinatal mortality also decreased significantly, while the decrease in the stillbirth rate was not statistically significant, pos- 
Table 2

Characteristics of prenatal and childbirth care in the BRISA cohort study, São Luís, Maranhão State, Brazil, 2010.

\begin{tabular}{|c|c|c|}
\hline Variables & $\mathrm{n}$ & $\%$ \\
\hline \multicolumn{3}{|l|}{ Attended prenatal care } \\
\hline Yes & 5,063 & 98.0 \\
\hline No & 103 & 2.0 \\
\hline \multicolumn{3}{|l|}{ Number of prenatal visits } \\
\hline None & 103 & 2.0 \\
\hline $1-3$ & 537 & 10.5 \\
\hline $4-5$ & 1,149 & 22.2 \\
\hline$\geq 6$ & 3,117 & 60.3 \\
\hline Missing & 260 & 5.0 \\
\hline \multicolumn{3}{|c|}{ Trimester of beginning of prenatal care } \\
\hline No prenatal care & 103 & 2.0 \\
\hline First & 3,418 & 66.2 \\
\hline Second & 1,426 & 27.6 \\
\hline Third & 117 & 2.3 \\
\hline Missing & 102 & 2.0 \\
\hline \multicolumn{3}{|l|}{ Category of prenatal care * } \\
\hline No prenatal care & 103 & 2.0 \\
\hline SUS & 4,123 & 79.9 \\
\hline Health plan/Health insurance & 702 & 13.6 \\
\hline Private & 230 & 4.5 \\
\hline \multicolumn{3}{|l|}{ Type of delivery * } \\
\hline Vaginal & 2,710 & 52.5 \\
\hline Cesarean & 2,456 & 47.5 \\
\hline \multicolumn{3}{|c|}{ Tubal ligation during cesarean delivery * } \\
\hline Yes & 502 & 9.8 \\
\hline No & 4,644 & 90.2 \\
\hline \multicolumn{3}{|l|}{ Professional attending delivery * } \\
\hline Doctor & 4,883 & 94.9 \\
\hline Nurse & 200 & 3.9 \\
\hline Other & 61 & 1.2 \\
\hline \multicolumn{3}{|c|}{ The same doctor provided prenatal care and attended delivery * } \\
\hline Yes & 892 & 17.3 \\
\hline No & 4,270 & 82.7 \\
\hline \multicolumn{3}{|l|}{ Category of admission * } \\
\hline SUS & 4,345 & 84.1 \\
\hline Health insurance & 656 & 12.7 \\
\hline Private & 164 & 3.2 \\
\hline Total & 5,166 & 100.0 \\
\hline
\end{tabular}

SUS: Brazilian Unified National Health System.

* Missing values were excluded.

sibly due to low numbers in the earlier cohort to assess differences in very rare outcomes. This is consistent with the findings in the Pelotas cohorts, where all these rates fell from 1982 to 2004 ?

Childbirth among women younger than 20 years (teenage pregnancy) decreased by $36.9 \%$ in São Luís from 1997/1998 to 2010, but still repre- sented a large proportion of all births. In contrast, there was an increase in the teenage pregnancy rate in the Ribeirão Preto cohorts from 1978/1979 to 1994 , reaching 17.5 in the latter 41 . However, more recent birth registry data agree with the findings in São Luís and indicate that the teenage pregnancy rate is falling in Brazil, from $23.5 \%$ in 
Sex of the newborn, intrauterine growth restriction and characteristics of health care provided to the newborns. BRISA cohort study, São Luís, Maranhão State, Brazil, 2010.

\begin{tabular}{lcc}
\hline Variables & $\mathbf{n}$ & $\%$ \\
\hline Sex & & 50.9 \\
Male & 2,631 & 49.1 \\
Female & 2,535 & 48.9 \\
Professional who attended the newborn & & 19.4 \\
Pediatrician/Neonatologist & 2,527 & 1.5 \\
Obstetrician & 1,001 & 17.8 \\
Anesthesiologist & 77 & 5.7 \\
Nurse & 917 & 0.2 \\
Nurse technician & 295 & 6.5 \\
Other & 12 & 100.0 \\
Missing & 337 & 98.2 \\
Determination of Apgar score & & 1.8 \\
Yes & 5,073 & 93 \\
No & 5,166 & \\
\hline Total & & \\
\hline
\end{tabular}

1997 to $19.3 \%$ in 2011 (Health Informatics Department. Nascidos vivos - Brasil, 2013. http:// tabnet.datasus.gov.br/cgi/tabcgi.exe?sinasc/ cnv/nvuf.def, accessed on 12/Dec/2013), probably reflecting younger women's greater access to contraceptive methods and better knowledge of reproductive issues.

Meanwhile, there was an $83.7 \%$ increase from 1997/1998 to 2010 in the number of pregnant women aged 35 years or older. Despite this increase, the percentage of childbirths among women aged 35 years or more is lower than in other Brazilian cities such as Rio de Janeiro 42, Pelotas 43, and Aracaju 1.

In São Luís, from 1997/1998 to 2010, social determinants associated with perinatal health improved, with emphasis on the reduction of low maternal schooling (less than 4 years of study). Similar results were shown in the Ribeirão Preto cohorts from 1978/1979 to 199438 and in the Pelotas cohorts from 1982 to 200444 .

Another positive change was a $21.7 \%$ reduction from 1997/1998 to 2010 in births to single mothers in the two São Luís cohorts. This result differs from the findings in the Ribeirão Preto 38 and Pelotas 44 cohorts, showing an increase in the percentage of births to single mothers. Even so, this indicator in the two municipalities of the Southeast and South regions is still lower than that of São Luís in 2010.

Prenatal care coverage increased by $6.8 \%$ in São Luís from 1997/1998 to 2010, although access was still not universal, with about $2 \%$ of all pregnant women still receiving no care. Similar results were also shown in Ribeirão Preto, where prenatal care coverage increased from 1997/1998 to 199445 and in Pelotas from 1982 to 2004 46, values similar to that of São Luís in 2010. Another favorable indicator in São Luís was early beginning of prenatal care, with an $11 \%$ absolute increase in the first prenatal visit in the first trimester, covering up to $67.5 \%$ of pregnant women in 2010. In Ribeirão Preto, in 1994, 64\% of pregnant women had started prenatal care in the first trimester 47 , a rate close to that observed in São Luís in 2010. The studies consistently show a marked increase in prenatal care coverage, in the appropriate number of prenatal visits, and in prenatal care starting in the first trimester. This favorable trend in prenatal care contributed to the declining PMR and IUGR rate.

On the negative side, the cesarean rate increased by $39.3 \%$ from 1997/1998 to 2010 in São Luís, reaching $47.5 \%$ in 2010 . The cesarean rate also increased in Ribeirão Preto from 1997/1998 to 199420 and in Pelotas from 1982 to 2004 46. The cesarean rates in all three municipalities were far higher than the $15 \%$ limit considered acceptable by the WHO 21,22.

A limitation of the present study was the existence of only two observations over time, which did not allow the study of temporal trends, although it did permit the identification of temporal changes, providing information for the implementation of public policies with a potentially positive impact. In addition, the limited number 
Table 4

Comparison of perinatal health indicators in two birth cohorts. São Luís, Maranhão State, Brazil, 1997/1998 and 2010.

\begin{tabular}{|c|c|c|c|c|c|}
\hline \multirow[t]{2}{*}{ Variables } & \multicolumn{2}{|c|}{$1997 / 1998$} & \multicolumn{2}{|c|}{2010} & \multirow[t]{2}{*}{$\mathrm{p}$-value * } \\
\hline & $\mathbf{n}$ & $\%$ & $\mathbf{n}$ & $\%$ & \\
\hline Low birth weight & & & & & 0.867 \\
\hline No & 2,275 & 91.5 & 4,706 & 91.4 & \\
\hline Yes & 212 & 8.5 & 445 & 8.6 & \\
\hline Preterm birth & & & & & 0.764 \\
\hline No & 2,164 & 86.8 & 4,497 & 87.1 & \\
\hline Yes & 329 & 13.2 & 669 & 12.9 & \\
\hline Classification of weight for gestational age ** & & & & & $<0.001$ \\
\hline Small for gestational age & 345 & 13.9 & 547 & 10.6 & \\
\hline Adequate for gestational age & 1,943 & 78.1 & 4,187 & 81.0 & \\
\hline Large for gestational age & 199 & 8.0 & 432 & 8.4 & \\
\hline Type of delivery & & & & & $<0.001$ \\
\hline Vaginal & 1,643 & 65.9 & 2,710 & 52.5 & \\
\hline Cesarean & 850 & 34.1 & 2,456 & 47.5 & \\
\hline Maternal age (years) & & & & & $<0.001$ \\
\hline$<20$ & 728 & 29.3 & 954 & 18.5 & \\
\hline $20-34$ & 1,657 & 66.5 & 3,805 & 73.6 & \\
\hline 35 or more & 106 & 4.3 & 407 & 7.9 & \\
\hline Maternal schooling (years) & & & & & $<0.001$ \\
\hline 12 or more & 120 & 4.8 & 779 & 15.1 & \\
\hline $9-11$ & 880 & 35.4 & 2,983 & 57.9 & \\
\hline $5-8$ & 1,059 & 42.6 & 1,156 & 22.4 & \\
\hline $1-4$ & 273 & 11.0 & 208 & 4.0 & \\
\hline 0 & 155 & 6.2 & 26 & 0.5 & \\
\hline Marital status & & & & & $<0.001$ \\
\hline Married & 717 & 28.8 & 1,126 & 21.8 & \\
\hline Consensual union & 1,167 & 46.8 & 3,053 & 59.1 & \\
\hline Single & 608 & 24.4 & 987 & 19.1 & \\
\hline Prenatal care & & & & & $<0.001$ \\
\hline No & 203 & 8.2 & 103 & 2.0 & \\
\hline Yes & 2,262 & 91.8 & 5,063 & 98.0 & \\
\hline Beginning of prenatal care & & & & & $<0.001$ \\
\hline No prenatal care & 203 & 8.2 & 103 & 2.0 & \\
\hline First trimester & 1,401 & 56.5 & 3,418 & 67.5 & \\
\hline Second trimester & 799 & 32.2 & 1,426 & 28.2 & \\
\hline Third trimester & 79 & 3.2 & 117 & 2.3 & \\
\hline \multicolumn{6}{|l|}{ Infant mortality rate } \\
\hline No & 2,422 & & 5,100 & & \\
\hline Yes & 71 & $35.8 * * *$ & 66 & 16.2 *** & $<0.001$ \\
\hline \multicolumn{6}{|l|}{ Neonatal mortality rate } \\
\hline No & 2,443 & & 5,120 & & \\
\hline Yes & 50 & 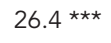 & 46 & $11.9 \star \star \star$ & $<0.001$ \\
\hline \multicolumn{6}{|l|}{ Perinatal mortality rate } \\
\hline No & 2,448 & & 5,128 & & \\
\hline Yes & 93 & 44.7 *** & 108 & $25.0 * \star \star$ & $<0.001$ \\
\hline \multicolumn{6}{|l|}{ Stillbirth rate } \\
\hline No & 2,493 & & 5,166 & & \\
\hline Yes & 48 & $25.0 * \star \star$ & 70 & $16.9 * \star \star$ & 0.062 \\
\hline
\end{tabular}

Note: the totals for some variables may differ because of missing values. Percentages may not reach $100 \%$ because of rounding.

* $\mathrm{p}$-value calculated excluding missing data;

** Classification of weight for gestational age according to the curve of Williams et al. 27 ;

*** Per 1,000 . 
of birth cohorts in Brazil hinders the comparison of perinatal indicators and visualization of regional disparities. However, São Luís is the capital of one Brazil's poorest states, while the cities of Ribeirão Preto and Pelotas belong to states with better socioeconomic indicators, thus allowing comparison of dissimilar social situations. Another limitation was the high percentage of missing data for income.

On the positive side, this was the first study to compare two population-based birth cohorts in Northeast Brazil. Although data collection involved a large number of interviewers, these professionals were properly trained and monitored by supervisors who checked the lists of hospital births daily and worked to reduce losses. Probabilistic sampling also reduced the likelihood of selection bias, and the large sample size allowed highly precise estimates of the target indicators. Since the data were collected in the first hours postpartum and were also obtained from patients' medical records, the probability of recall bias was low.

In conclusion, we observed favorable evolution in various perinatal indicators, which may have contributed to reducing the IUGR rate and IMR in São Luís. However, while some sociodemographic and behavioral factors and health services utilization improved, the PTB and LBW rates remained stable and the cesarean rate increased. 


\section{Resumen}

El objetivo de este estudio fue analizar los cambios de la salud perinatal en dos cohortes de nacimiento realizadas en 1997/1998 y 2010 en São Luís, Maranhão, Brasil. Un total de 2.493 niños nacidos vivos fueron incluidos en 1997/1998 y 5.166 en 2010. La tasa de bajo peso al nacer (BPN) no cambió (8,5\% y 8,6\%). La tasa del nacimiento prematuro (TNP) también se mantuvo estable (13,2\% y 13\%). Los nacimientos entre adolescentes y madres solteras disminuyeron. La escolaridad de la madre y la cobertura de atención prenatal aumentaron. La tasa de restricción del crecimiento intrauterino (RCIU) se redujo de un 13,3\% a un 10,6\% (p $<0,001)$. La tasa de mortalidad perinatal disminuyó de 36,6 a 20,7 por mil ( $p<0,001)$, y la tasa de mortalidad infantil (TMI) se redujo de 28,5 a 12,8 por mil ( $p$ $<0,001)$. La tasa de cesárea (TC) aumentó de 34,1\% a $47,5 \%(p<0,001)$. A pesar de los cambios favorables en factores sociodemográficos, de conducta y de servicios de salud, y de la reducción de RCIU, mortalidad perinatal e infantil, las tasas de BPN y el PTB se mantuvieron estables, mientras que la TC aumentó.

Recién Nacido de Bajo Peso; Nacimiento Prematuro; Retardo del Crecimiento Fetal; Cesárea;

Estudios de Cohorte

\section{Contributors}

A. A. M. Silva conceived the study, performed the statistical analysis, analyzed the data, and wrote, read and approved the final version of the manuscript. R. F. L. Batista and E. B. A. F. Thomaz performed the statistical analysis, analyzed the data, and read and approved the final version of the manuscript. V. M. F. Simões, C. C. C. Ribeiro, F. Lamy-Filho, Z. C. Lamy, M. T. S. S. B. Alves, F. H. F. Loureiro and V. C. Cardoso analyzed the data and read and approved the final version of the manuscript. H. Bettiol and M. A. Barbieri conceived the study, analyzed the data, and read and approved the final version of the manuscript.

\section{Acknowledgments}

The authors wish to thank the interviewers and the mothers who kindly agreed to participate in the study.

\section{References}

1. Gurgel RQ, Nery AMDAG, Almeida MLD, Oliveira ERR, Lima DDF, Bettiol H, et al. Características das gestações, partos e recém-nascidos da região metropolitana de Aracaju, Sergipe, Brasil. Rev Bras Saúde Matern Infant 2009; 9:167-77.

2. Bettiol H, Barbieri MA, Silva AAM. Epidemiologia do nascimento pré-termo: tendências atuais. Rev Bras Ginecol Obstet 2010; 32:57-60.

3. Santos IS, Barros AJ. From the uterus to 12 months of age: changes in the maternal-child health profile in three birth cohorts in Pelotas, Rio Grande do Sul State, Brazil, 1982-2004. Cad Saúde Pública 2008; 24 Suppl 3:S368-9.
4. Silva AA, Ribeiro VS, Borba Jr. AF, Coimbra LC, Silva RA. Avaliação da qualidade dos dados do Sistema de Informações sobre Nascidos Vivos em 19971998. Rev Saúde Pública 2001; 35:508-14.

5. Barros FC, Matijasevich A, Requejo JH, Giugliani E, Maranhão AG, Monteiro CA, et al. Recent trends in maternal, newborn, and child health in Brazil: progress toward millennium development goals 4 and 5. Am J Public Health 2010; 100:1877-89. 
6. Passini Jr. R, Tedesco RP, Marba ST, Cecatti JG Guinsburg R, Martinez FE, et al. Brazilian multicenter study on prevalence of preterm birth and associated factors. BMC Pregnancy Childbirth 2010; 10:22.

7. Barros FC, Victora CG, Barros AJ, Santos IS, Albernaz E, Matijasevich A, et al. The challenge of reducing neonatal mortality in middle-income countries: findings from three Brazilian birth cohorts in 1982, 1993, and 2004. Lancet 2005; 365:847-54.

8. Edwards NM, Audas RP. Trends of abnormal birthweight among full-term infants in Newfoundland and Labrador. Can J Public Health 2010; 101:13842.

9. Horbar JD, Carpenter JH, Badger GJ, Kenny MJ, Soll RF, Morrow KA, et al. Mortality and neonatal morbidity among infants 501 to 1500 grams from 2000 to 2009. Pediatrics 2012; 129:1019-26.

10. Lau C, Ambalavanan N, Chakraborty H, Wingate MS, Carlo WA. Extremely low birth weight and infant mortality rates in the United States. Pediatrics 2013; 131:855-60.

11. World Health Organization; March of Dimes; The Partnership for Maternal, Newborn, \& Child Health; Save the Children. Born too soon: the global action report on preterm birth. Geneva: World Health Organization; 2012.

12. Blencowe H, Cousens S, Oestergaard MZ, Chou D, Moller AB, Narwal R, et al. National, regional, and worldwide estimates of preterm birth rates in the year 2010 with time trends since 1990 for selected countries: a systematic analysis and implications. Lancet 2012; 379:2162-72.

13. Bettiol H, Rona RJ, Chinn S, Goldani M, Barbieri MA. Factors associated with preterm births in southeast Brazil: a comparison of two birth cohorts born 15 years apart. Paediatr Perinat Epidemiol 2000; 14:30-8.

14. Barros FC, Victora CG, Matijasevich A, Santos IS, Horta BL, Silveira MF, et al. Preterm births, low birth weight, and intrauterine growth restriction in three birth cohorts in Southern Brazil: 1982, 1993 and 2004. Cad Saúde Pública 2008; 24 Suppl 3:S390-8.

15. Veloso HJ, Silva AA, Barbieri MA, Goldani MZ, Lamy Filho F, Simões VM, et al. Secular trends in the rate of low birth weight in Brazilian State Capitals in the period 1996 to 2010. Cad Saúde Pública 2013; 29:91-101.

16. Barbieri MA, Silva AA, Bettiol H, Gomes UA. Risk factors for the increasing trend in low birth weight among live births born by vaginal delivery, Brazil. Rev Saúde Pública 2000; 34:596-602.

17. Lee AC, Katz J, Blencowe H, Cousens S, Kozuki N, Vogel JP, et al. National and regional estimates of term and preterm babies born small for gestational age in 138 low-income and middle-income countries in 2010. Lancet Glob Health 2013; 1: e26-36.

18. De Farias Aragão VM, Barbieri MA, Moura Da Silva AA, Bettiol H, Ribeiro VS. Risk factors for intrauterine growth restriction: a comparison between two Brazilian cities. Pediatr Res 2005; 57(5 Pt 1):674-9.
19. Victora CG, Aquino EM, do Carmo Leal M, Monteiro CA, Barros FC, Szwarcwald CL. Maternal and child health in Brazil: progress and challenges. Lancet 2011; 377:1863-76.

20. Gomes UA, Silva AA, Bettiol H, Barbieri MA. Risk factors for the increasing caesarean section rate in Southeast Brazil: a comparison of two birth cohorts, 1978-1979 and 1994. Int J Epidemiol 1999; 28:687-94.

21. World Health Organization. Appropriate technology for birth. Lancet 1985; 2:436-7.

22. Ye J, Betran AP, Guerrero Vela M, Souza JP, Zhang J. Searching for the optimal rate of medically necessary cesarean delivery. Birth 2014; 41:237-44.

23. Goldani MZ, Barbieri MA, Rona RJ, Da Silva AA, Bettiol H. Increasing pre-term and low-birthweight rates over time and their impact on infant mortality in south-east Brazil. J Biosoc Sci 2004; 36:177-88.

24. Silva AAM, Coimbra LC, Silva RA, Alves MTSSB, Lamy Filho F, Lamy ZC, et al. Perinatal health and mother-child health care in the municipality of São Luís, Maranhão State, Brazil. Cad Saúde Pública $2001 ; 17: 1413-23$.

25. United Nations Development Program. Atlas of Human Development, Brazil, 2013. http://www. atlasbrasil.org.br/2013/perfil/sao-luis_ma (accessed on 08/Aug/2013).

26. Rosner B. Fundamentals of biostatistics. Boston: Brooks/Cole/Cengage Learning; 2010.

27. Williams RL, Creasy RK, Cunningham GC, Hawes WE, Norris FD, Tashiro M. Fetal growth and perinatal viability in California. Obstet Gynecol 1982; 59:624-32.

28. Altman DG, Coles EC. Nomograms for precise determination of birth weight for dates. Br J Obstet Gynaecol 1980; 87:81-6.

29. Camargo Jr. KR, Coeli CM. Reclink: aplicativo para o relacionamento de bases de dados, implementando o método probabilistic record linkage. Cad Saúde Pública 2000; 16:439-47.

30. Silva AA, Barbieri MA, Gomes UA, Bettiol H. Trends in low birth weight: a comparison of two birth cohorts separated by a 15-year interval in Ribeirao Preto, Brazil. Bull World Health Organ 1998; 76:7384.

31. Silva AA, Silva LM, Barbieri MA, Bettiol H, Carvalho LM, Ribeiro VS, et al. The epidemiologic paradox of low birth weight in Brazil. Rev Saúde Pública 2010; 44:767-75.

32. Silveira MF, Santos IS, Matijasevich A, Malta DC, Duarte EC. Nascimentos pré-termo no Brasil entre 1994 e 2005 conforme o Sistema de Informações sobre Nascidos Vivos (SINASC). Cad Saúde Pública 2009; 25:1267-75.

33. Silveira MF, Santos IS, Barros AJ, Matijasevich A, Barros FC, Victora CG. Increase in preterm births in Brazil: review of population-based studies. Rev Saúde Pública 2008; 42:957-64.

34. Silva AA, Bettiol H, Barbieri MA, Brito LG, Pereira MM, Aragão VM, et al. Which factors could explain the low birth weight paradox? Rev Saúde Pública 2006; 40:648-55. 
35. Silva AA, Bettiol H, Barbieri MA, Pereira MM, Brito LG, Ribeiro VS, et al. Why are the low birthweight rates in Brazil higher in richer than in poorer municipalities? Exploring the epidemiological paradox of low birthweight. Paediatr Perinat Epidemiol 2005; 19:43-9.

36. Silva CH, Goldani MZ, Silva AA, Agranonik M, Bettiol H, Barbieri MA, et al. The rise of multiple births in Brazil. Acta Paediatr 2008; 97:1019-23.

37. Da Silva CH, Agranonik M, Da Silva AA, Bettiol H, Barbieri MA, Goldani MZ. Secular trend of very low birth weight rate in Porto Alegre, Southern Brazil. J Biosoc Sci 2010; 42:243-53.

38. Goldani MZ, Bettiol H, Barbieri MA, Tomkins A. Maternal age, social changes, and pregnancy outcome in Ribeirao Preto, southeast Brazil, in 197879 and 1994. Cad Saúde Pública 2000; 16:1041-7.

39. Santos IS, Menezes AM, Mota DM, Albernaz EP, Barros AJ, Matijasevich A, et al. Infant mortality in three population-based cohorts in Southern Brazil: trends and differentials. Cad Saúde Pública 2008; 24 Suppl 3:S451-60.

40. Goldani MZ, Benatti R, da Silva AA, Bettiol H, Correa JC, Tietzmann M, et al. Narrowing inequalities in infant mortality in Southern Brazil. Rev Saúde Pública 2002; 36:478-83.

41. Ribeiro ER, Barbieri MA, Bettiol H, da Silva AA. Comparison of two cohorts of adolescent mothers in a municipality in Southeast Brazil. Rev Saúde Pública 2000; 34:136-42.

42. Leal MC, Gama SGN, Campos MR, Cavalini LT, Garbayo LS, Brasil CLP, et al. Fatores associados à morbi-mortalidade perinatal em uma amostra de maternidades públicas e privadas do Município do Rio de Janeiro, 1999-2001. Cad Saúde Pública 2004; 20 Suppl 1:S20-33.
43. Santos IS, Barros AJ, Matijasevich A, Tomasi E, Medeiros RS, Domingues MR, et al. Mothers and their pregnancies: a comparison of three population-based cohorts in Southern Brazil. Cad Saúde Pública 2008; 24 Suppl 3:S381-9.

44. Barros AJD, Santos IS, Matijasevich A, Araujo CL, Gigante DP, Menezes AMB, et al. Methods used in the 1982, 1993, and 2004 birth cohort studies from Pelotas, Rio Grande do Sul State, Brazil, and a description of the socioeconomic conditions of participants' families. Cad Saúde Pública 2008; 24 Suppl 3:S371-80.

45. Goldani MZ, Barbieri MA, Silva AA, Bettiol H. Trends in prenatal care use and low birthweight in southeast Brazil. Am J Public Health 2004; 94:136671.

46. Cesar JA, Matijasevich A, Santos IS, Barros AJD, Dias-da-Costa JS, Barros FC, et al. The use of maternal and child health services in three populationbased cohorts in Southern Brazil, 1982-2004. Cad Saúde Pública 2008; 24 Suppl 3:S427-36.

47. Bettiol H, Barbieri MA, Gomes UA, Andrea M, Goldani MZ, Ribeiro ER. Perinatal health: methodology and characteristics of the study population. Rev Saúde Pública 1998; 32:18-28.

Submitted on $30 /$ Jun/2014

Final version resubmitted on 05/Nov/2014 Approved on 10/Nov/2014 